\title{
The Brand Value in a New Concept of Hotel: The Albergo Diffuso Sextantio Case
}

\author{
Barbara Iannone $^{1}$, \& Liliana Marcella ${ }^{2}$ \\ ${ }^{1}$ Department of Philosophical, Pedagogical and Economic-Quantitative Sciences, University “G. d'Annunzio”of \\ Chieti, Pescara, Italy \\ ${ }^{2}$ Accountant, Managing Director Carlo Maresca Group S.p.A., Italy \\ Correspondence: Barbara Iannone, Department of Philosophical, Pedagogical and Economic-Quantitative \\ Sciences, University “ G. d’Annunzio”of Chieti-Pescara Viale Pindaro, 42 Pescara, Italy.
}

Received: July 25, 2019

doi:10.5539/ibr.v12n9p81

\author{
Accepted: August 8, 2019 \\ Online Published: August 29, 2019 \\ URL: https://doi.org/10.5539/ibr.v12n9p81
}

\begin{abstract}
The phenomenon of Albergo Diffuso (AD) represents an important development in the competitiveness between destinations and concerns the way in which historical and cultural heritage is used. The concept of AD is a new and innovative meaning of tourism which promotes the sustainable future through the recovery of ancient towns and, in the same time, developes further ways to create entrepreneurship.

The goal of this work consists of the economic valuation model and conceptual defining of brand value referred to one case study of $\mathrm{AD}$, Sextantio. It is made up of two parts: the first consists of a contextualization of one of the traditional formulas of Financial-Standard Method of Brand Value, because of the features of brand value in an economic content; the second part consists of a first classification of elements which are tangible and intangible to a brand of $\mathrm{AD}$, related to the specific elements and based on different key performance indicators (KPI), deriving from elements generally relevant in hospitality tourism, and far more in this new concept than against the traditional concept of tourism.
\end{abstract}

Keywords: Albergo Diffuso (AD), intangibles, brand value, sextantio

\section{Introduction}

The concept of brand in literature is characterized by different approaches, thus, brand is defined by different researchers and authors in different ways.

Starting from one of the first definition of brand was referred to a name, a logo, a trademark, or a symbol (Aaker, 1991). Later, brand equity was defined as "a set of assets and liabilities linked to a brand, its name and symbol, which adds to or subtracts from the value provided by a product or service to a firm and/or to that firm's customers"(Giovannini et al., 2017: p. 18). The "assets" and "liabilities" are closely linked to the context and they can be synthesized in brand loyalty, reputation, perceived quality, other values associated with the brand and other unique resources belonging to the brand.

Branding as "endowing products and services with the power of a brand", thus a brand is a "perceptual entity that is rooted in reality but reflects the perception and perhaps even the idiosyncrasies of consumers" (Kotler and Keller, 2006:275). Researchers generally agree that brands are endowed with personalities and that consumers have the tendency to choose brands whose personality fit their own. Generally, brand positioning refers to how the brand is placed in the minds of the consumers and compares to other competing products or services (Chacko, 1997).

Once the brand was assigned to consumer goods but, in the last decades, it is applicable to places and/or attractions (Hankinson, 2004). In this vein, the destination branding (Nickerson \& Moisey, 1999; Brent et al., 1998; Henderson, 2007) and lastly the phenomenon of AD have introduced a new winde concept of Brand: in the field of tourism, often refers to the traditional notion of hotel and it is not considered the place where the attractions and hospitality are found (Cooper et al, 2005). One of the last best definition od Destanation brand was the following: " a set of marketing activities that support the creation of a name, symbol, logo, word, mark or the other graphic that readily identifies and differentiates a destination consistently conveys the expectations of a memorable experience that is uniquely associated with the destination, that serve to consolidate and 
reinforce the emotional connection between the visitor and the destination and that reduces consumers search costs and perceived risk. Collectively these serve to create a destination image that positively influences consumer destination choice" (Blain et al., 2005:337).

The formula of $\mathrm{AD}$ are tourists' attractions which transform historical towns and villages into "destinations with hotel included". In this vein, AD has been gaining importance because it allows opportunities for regeneration related to these sites. This is the reason why that traditional concept of hotel's brand is limited to the only tangible or a few elements of intangible assets.

The present study attempts to identify, in a firts step of research into the AD, which factors should be considered in building a process of brand value and subsequently for a future economic evaluation model referring to the specific formula of $\mathrm{AD}$.

\section{Theoretical Background}

\subsection{Towards a New Concept of Hotel: The AD (Albergo Diffuso)}

The hotel attributes thought to appeal to customers, are generally studied from three perspectives: 1) before the actual booking, 2) during the stay at the hotel, and 3) after the hotel experience (Dolnicar \& Otter, 2003). They are tangible and intangible. Including in the tangible category, are hotel facilities such as the bar/lounge , swimming pool, SPA area, wellness area and so on; intangible attributes include cleanliness, comfort, and security (Atkinson, 1988; Cadotte \& Turgeon, 1988; Callan \& Bowman, 2000; Dube \& Renaghan, 2000; Lockyer, 2005; Poon \& Low, 2005; Wilkins, et al., 2007; Haghkhah et al., 2011; Lin, 2012). Furthermore they are futures to increase customer loyalty such as meal quality, staff attitude, hotel decoration, convenient parking, service customization and reasonable price. Finally, the enhancement of a hotel's web services (i.e., providing an online reservation system and travel information) can make travel arrangements more convenient for customers, and thus build competitive advantages (Chung et al., 2004; Poon \& Low, 2005).

If an hotel can let perceive its intangible value, as, referring to a store: "those attributes projected by the product's (store's) image which lead to the choice of the product (store) may be called determinant, since they determine preference and purchase" (Alpert, 1971:184). The meaning is that if the hotel's characteristics or features that appeal to customers include these determinant attributes, then the business has already obtained some of the key factors for business success. These key factors may include cleanliness, location, price, security, service quality, hotel reputation, and value for money (Lewis \& Chambers, 2000; Gonçalves at al., 2018; Jerman \& Janković, 2018). Absolutely, hotel service quality, staff attitude and professional knowledge are very important for customers during their stay at a hotel (Cadotte \& Turgeon, 1988). Thus, in a traditional approach, the service customization, hotel image and value for money should be the focus of hotel managers. Furthermore, people from different cultures may have different preferences (Poon \& Low, 2005).

It is widely known, that more and more mass industrial tourism has been strongly criticised as unsustainable. In contrast to this, new forms of tourism have emerged as sustainable tourism, that have been of interest to various categories of stakeholders (Ioppolo et al., 2013; Jamal et al., 2013; Moscardo \& Murphy, 2014; Giampiccoli \& Saayman, 2014). Tourists themselves have evolved over the years (Kastenholz, 2004) they want a personalised tourist experience (Buonincontri et al., 2017), look for authenticity (Peterson, 2005), they have a great interest in the environment and territory (Lanfranchi et al., 2014; Simone et al., 2018), and view their holiday as an opportunity to improve their knowledge of cultures and places (Villani \& Dall'Ara, 2015). These new aspects are reflected in the hotel's strategies based on a co-evolutionary approach from-territory in experiential perspective (Cucari et al., 2019). The Albergo Difuso is one of the best example of this evolution: a new way through old or historic structures. Albergo Diffuso (AD) is "a sustainable and innovative form of hotel that originates in enhancing historical and cultural real estate heritage, characterized by original structures, places (rural areas or small urban centres) and persons involved (both residents and tourists) in the production-distribution process and with experiential authenticity" (Paniccia \& Leoni, 2017, p.6). The model of hospitality AD, rigorously a Made in Italy, could be summarised as a solution that respects the environment and the cultural identity of a place (Confalonieri, 2011; Dall'Ara, 2010).

It was born in the Friuli Region, in 1982, in order to create policies that will prevent the depopulation of rural areas and safeguard the landscape and with the intention of restoring houses and small villages with post-earthquake funds. It consists of rooms dispersed throughout different buildings across a town, with each room generally no more than 200-300 mt. away from the central hub, and offers a reception, orientation area and service centre of tourism. More and more, this model of hotel has increased year by year, as a new concept of territorial development, by enhancing the peculiarities of the Italian scenario through the reuse of small historical towns and villages. The goal of these different revitalization tactics is to eliminate the risk of permanently losing 
notable heritage including buildings, spaces, culture, history and identities. It also prevents the depopulation of small villages, by enhancing public assets such as history, culture, natural resources, infrastructures and private assets such as private homes, enterprises and maufactures (Confalonieri, 2011). In this model, AD represents a form of integration in the territory, where the community is the main element of the hospitality services being provided (Villani \& Dall'Ara, 2015). It has the following features: joint enterprise, a single management hospitality services and related activities; basic services for residents and tourists such as accommodation, breakfast, housekeeping, restaurants, and other similar such as shuttle buses to reach main local tourist attractions, knowledge of local tradition including culture and cuisine that can be reimagined, special events and initiatives organised for the improvement and preservation of the area; residential dwellings located in separate pre-existing buildings, within the inhabited old town centre; limited distance between residential dwellings, rooms and common areas: at most 200-300 meters between them; presence of reception desks in central positions; presence of residents who welcome relationships with tourists and at the same time preserve traditional culture due to their sense of belonging; safeguarding of an authentic environment, characterized by the interaction with the social milieu and local culture; "recognizability" of a place, due to its well defined and homogenous identity, the brand of a territory.

Thus, the $\mathrm{AD}$, according to this conception, is in line with needs related to emerging sustainable tourism, which is increasingly responsive to the environment and local communities (Cater \& Lownam, 1994): in order to limit the various impacts on the environment (Vallone \& Veglio, 2014). Lastly, another relevant effect of this formula is the promotion of the economic development of the territory: in this way, it can help the economic and community development in areas where often the only valuable resource is just the landscape with its historic heritage and traditions. The first definition of "Albergo Diffuso" appeared in the Regional Law of Sardinia L.R.S n. 22/1984. It was defined here as facilities characterised "by the concentration in a single building of reception, common areas and possibly a restaurant and kitchen, and by the distribution of the residential units in one or more separate buildings, provided that they be located in the old town centre of the municipality and are not more than 200 metres away from the building where main services are located" (Trombino, 2009). A further contribution from Sardinia came with the law "12.08.1998, n. 27, Article 25" which confers an independent form of accommodation facility to the AD (Vignali, 2010).

This model is interesting as in Italy, where it was born, as also in the many other countries throughout the world where it has been reproduced (Avram \& Zarrilli, 2012; Di Clemente et al., 2014; Liçaj, 2014; Durkin \& Kolarić, 2016; Giampiccoli \& Saayman, 2016). In this vein, it has changed the concept of Brand referring to the Hotel according to this new solution of tourism hospitality: the AD. This research propose a study focused on a case study: Sextantio. The research questions that guide this paper are:

\section{RQ1: What is the brand value of Sextantio according to the financial perspective?}

RQ2: What are the new tangible and intangible elements related to the new concept of hospitality tourism of Albergo Diffuso?

\section{Method}

The aim of the paper is twofold. The first aim is to illustrate the "traditional" method of evaluating the brand referring to a case study selected in this research. The second aim is to identify the elements linked to a concept of $\mathrm{AD}$, beyond the elements of "traditional" hotels that result in the high quality of tourist hospitality. In order to reach these results, we following first of all, the theoretical model of Esposito De Falco (2012): a firm develops with the territory according to a path that promotes, throught a dynamic relationship, both the survival of the firm over time, and the enhancement of local capital. It is also adopted the rating coined by Droli (2013): he creates an analytical model that help select the most attractive and competitive rural hamlets where a business for hospitality duffused could be successfully set up. In order to obtain the goals of the study, this research adopts a case study methodology (Einsenhardt, 1989; Yin, 1994, 2009), as the best method to study this field of research in agreement with other researchers in this vein (Paniccia et al., 2007; Paniccia et al., 2010; Vallone \& Veglio, 2014; Presenza et al., 2019; Valeri \& Paoloni, 2017). However, the lack of an established theoretical model of $\mathrm{AD}$ and the exploratory nature of this research also suggest the use of a qualitative approach.

Therefore, the starting point is to adopt a quantitative approach through the evaluation model of Brand using the most common method: a method based on the cash flow. This study then adopts a qualitative method in order to identify the first element involved in brand definition, in particular reference to the Sextantio case, company, which was among the first to create a model of AD in Italy, starting to the experience of Santo Stefano di Sessanio ( province of L'Aquila ) and then in Matera, precisely in Grotte della Civita. Exploratory case study is useful when preliminary propositions and hypotheses are absent and it has been used in other studies to describe 
the development or management of other Ads, i.e. Borgo Tuf (Del Gatto, 2015); Borgo of Sempronio (Fissi et al., 2014), Sextantio (e.g. Paniccia et al., 2007, 2010; Tani \& Papaluca, 2015; Gorgo \& Riggi, 2017).

The analysis was conducted in two major stages. In the first stage, the method of royalties was adopted to evaluate the current brand value of Sextantio company. In the second stage a new framework is proposed to include the other factors (tangible and intangible) affectig the tourist perception in a Brand of AD, in a Brand Reputation value related to this innovative formula of hotel born by the regeneration of small villages.

\subsection{The Case Study - Sextantio}

Sextantio is one of the first AD born in Italy, initially in Santo Stefano di Sessanio in the Abruzzo Region. It consists of a fortified medieval village on top of the hill of Gran Sasso, $1250 \mathrm{mt}$, surrounded by mountains, within the National Park of Gran Sasso and the mountains of Laga.

At the end of the 1990's, Daniele Kihlgren, an Italian-Swedish entrepreneur, bought part of this village in order to recover its historic, cultural and artistic heritage.He adopted a humanistic and philosophical culture centered on anthropology, architecture and economy, molding the philosophy of this model of AD.

Sextantio was defined as a supreme example of regeneration of historic value together with the revitalization of small hostorical towns. Kihlgren affirmed that surrounding Santo Stefano di Sessanio there exists more than 20,000 historical small villages and municipalities that have a rich social capital, understood as the set of relation and, above all as underlined by scholars (Putmann et al., 1993), widespread civicness and trust, which facilitates cooperation between individuals. The starting point is the conservation of the original cubing, of the typological implants, destination of use and holes. It is involved the local economies thorough the use of the recyclable materials were taken from the surrounding areas. The various buildings are used to different uses: rooms, areas for conferences, restaurants, shops, areas for free time, etc., all within the same village.

More later, thanks to Kihlgren it was born another site: Matera, the resilient city. Matera can be proud of his historic center designated as UNESCO World Site in 1993 (the first in Southern Italy) an improved and enhanced tourism that has contributed to designated as the European Capital of Culture 2019. Furthermore, the site of Sassi of Matera is among the oldest in the world and proves the continued presence of humans from the Palaeolithic to the present. According to the philosophy of Rural Tourism, the design of tourist accommodation in this area uses traditional building methods and the original types of houses and materials: in this vein, the results is a saving of cultural goods in an innovative way.

Sextantio Albergo Diffuso Le Grotte della Civita was defined by the international press, as on of the most extraordinary touristic destination in the world and this place is among the ten most beautiful hotels in the world (e.g., The New York Times, The Guardian, National Geographic Traveler). In technical terms, the goal of this "hotel formula" of $\mathrm{AD}$ is to save any elements of the territorial identity: the architecture and local materials cultures from the craft tradition to the cuisine of the areas in a few words, the history and the entire landscape. Guests will live an atmosphere totally immersed in the cultural and human history of the Sassi of Matera, as confirmed by the comments of tourists. A major online booking platform claims that it is an "incredible opportunity to stay in highly unusual space", "special experience in staying at caves, going back in time machine", "luxurious stay in a unique cave environment" and "one of the most memorable places we ever stayed", with reference to a touristic personalized experience above mentioned (Gonçalves et al., 2018).

Daniele Kihlgren began, with his model of "special AD" has been recognised as an example of Italian excellence. As Kihlgren proudly shares, "finally, the administrators have understood that in order to protect the integrity of the villages, respecting the existing, using only local materials, not building anything, not adding anything, not changing anything, not increasing the volume, not changing the furniture, at most repairing and to adapting is the only way" (Cucari et al., 2019, p. 110).

\section{Results}

The importance of the "Sextantio" brand as an independent asset value in the field of tourism activities, thanks to the high level of differentiation and innovation, as described above, is quite evident. Sextantio identifies a new model of tourist destination, which has become a reference for international quality tourism that is recognizable compared to the others for the added value given to the village territory relationship and to the exclusive recovery and conservation of the existing heritage.

To obtain these goals, Daniele Kihlgren established the following Group: 


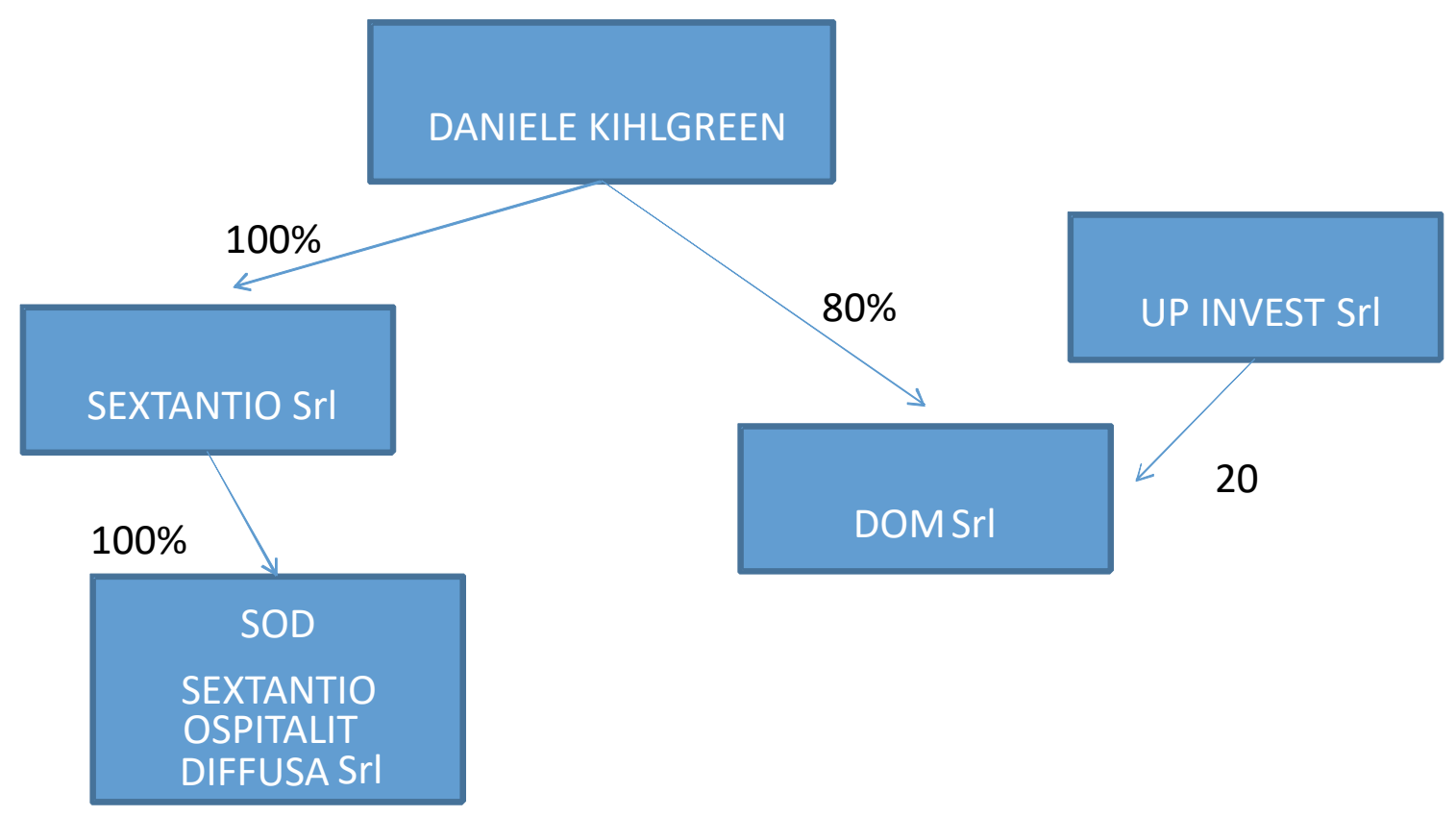

Figure 1. The Daniele Kihlgren Group

\subsection{The Process of Brand Evaluation in Sextantio}

The literature about the criteria of brand value is divided into two macro-groups: the criteria c.d. "analytical", whose logical construction is supported by documented information; the criteria c.d. "empirical", based on analyses and formulas derived from market trends, percentages or multipliers of given economic quantities, considered basic for the purposes of estimating certain intangibles (Guatri \& Bini, 2011).

The most used methods of brand value are following (Zanda et al., 2005):

a. the methods based on empirical indicators (by the application of a percentage or a multiplier to one variable considered qualifying for the element to be evaluated.

b. the methods based on economic-financial approach (by the contribution of the brand to profitability by discounting for several years, the differential income made by the brand itself;

c. the cost-based methods (it considers the historical cost, the revaluated historic cost compared to a ISTAT index, the replacement or reproduction cost, the cost of the loss);

d. the financial methods (considering the value of the cash flows generated by the brand available in the future years);

e. the methods based on royalties (the most used in practice of various firms).

The Sextantio brand certainly represents a luxury hotel in hospitality tourism, sharing a completely new perspective: the guest enjoys not just a simple stay, but a complete experience enriched with tastings of products prepared according to recipes and ingredients of the past, cultural routes, the possibility to buy and learn about local handicrafts, etc. In a constantly changing market, and with the emergence of new technologies that will revolutionize the hospitality sector, luxury hotels must move their strategy not only into the traditional tangible and intangible assets, but towards these new values. In this vein, they must offer and provide new exclusive services, supplementing the need to preserve the heritage, as Sextantio has been offerring for several years.

For these reasons, considering the activity performed and the availability of data, it was decided to apply the methods based on royalties, as a correct price that anyone would pay to manage an hotel business, making use of the original and particular experience of the Sextantio Group and adapting to already tested standards, relying on the marketing of services for a well-known brand.

The referring formula of this methods is: 


$$
W_{m}=\sum_{t=1}^{n} \frac{\left[\left(F_{t} * r-C_{t}\right) *(1-\operatorname{tax})\right]}{(1+i)^{t}}
$$

where:

Wm: current value of the Brand

$\mathrm{n}$ : time period considered

$\mathrm{F}_{\mathrm{t}}$ : sales expected on a time period corresponding to the residual life of the brand

r: royalty rate;

$\mathrm{C}$ : average annual maintenance costs

tax: tax rate

i: discounted rate.

The futher steps for application of the royalty-rate method are as follows:

a) assessment of the royalty rate;

b) assessment of the useful life of the brand;

c) assessment of expected sales and turnover growth rate;

d) assessment of the discounted rate;

e) final evaluation of Sextantio Brand Value.

\section{a. assessment of the royalty rate}

For the esteem of the royalty rate, reference is made to a study made by the HVS in 2013 "Hotel Franchise Fee Guide" where different hotel chains are compared which have adopted the franchising structure based on the royalty rate applied. Analyzing 33 hotel chains belonging to the luxury sector and assuming that the royalties were quantified in the Uniform Franchise Offering Circulars (UFOC) or in the Franchise Disclosure Document (FDD) prepared by each franchisor, it is noted that the royalty percentage applied is between $1.93 \%$ and $15.86 \%$ with a higher concentration in the range between $8 \%$ and $10 \%$. For this reason, it was decided to use the $10 \%$ as the percentage higher between the most applied rate by the analyzed hotels.

\section{b) assessment of the useful life of the brand}

With reference to the current protection system referred to the brand in Italy and in the European Community, the residual life guaranteed by legal protection is 9 years except for the renewals that occur every ten years. Furthermore, literature and the reference practice suggest a particularly prudent approach in estimating the useful life of the brands given their intrinsic volatility. In particular, a time horizon of 5-20 years with a strong concentration over 5-15 years is identified (Guatri \& Bini, 2011; Zanda et al., 2005).

In the Sextantio case, with the peculiarity of the activity that distinguishes it, it is prudent that the esteem of residual useful life of the brand is established in ten years.

\section{c) assessment of expected sales and turnover growth rate}

The basis on which the royalty is calculated is represented by the average turnovers estimated over the time period considered by the sale of the services identified by SOD and DOM brands.

Furthermore, the following historical data available and which is reported below, is considered the most significant period for the last five years.

\begin{tabular}{cccccc}
\hline $\begin{array}{c}\text { Consolidated data } \\
\text { SOD + DOM (in } € \text { ) }\end{array}$ & Year 2013 & Year 2014 & Year 2015 & Year 2016 & Year 2017 \\
\hline Total Revenues & 1.879 .189 & 1.984 .151 & 2.449 .934 & 2.503 .562 & 2.662 .938 \\
\hline
\end{tabular}

It must be considered that DOM has obtained another sub-concession from the Municipality of Matera for the management of another 14 rooms in the Sassi Area in addition to the 18 already existing and they should be operational by 2021 .

Therefore, making reference to the income components of the previous years, to the current market conditions 
and to the growth forecasts of the activity related to the Brand, the base of an average fair flow of revenues is Euro 2.296.000. It is revalued by five percent per year, except for the year 2021 in which a revaluation of revenues of $30 \%$ is applied thanks to the increased accommodation structure of Matera.

Following the expected sales for the years 2019-2028 (in Euro):

\begin{tabular}{llllllllll}
\hline 2019 & 2020 & 2021 & 2022 & 2023 & 2024 & 2025 & 2026 & 2027 & 2028 \\
\hline 2.296 .000 & 2.410 .000 & 3.133 .000 & 3.290 .000 & 3.454 .000 & 3.627 .000 & 3.808 .000 & 3.998 .000 & 4.198000 & 4.400 .000 \\
\hline
\end{tabular}

\section{d) assessment of the discounted rate.}

For the process of Brand evaluation, it is considered appropriate, as the literature and practice suggested, in the case of intangibles with a definite useful life, to use a rate that represents the average cost of the capital invested in the company. This rate is called the Weighted Average Cost of Capital (WACC), defined as follows:

$$
\mathrm{WACC}=\mathrm{W}_{\mathrm{e}} \cdot \mathrm{I}_{\mathrm{e}}+\mathrm{W}_{\mathrm{u}} \cdot \mathrm{I}_{\mathrm{u}} \cdot(1-\mathrm{t})
$$

where:

$\mathrm{W}_{\mathrm{e}}$ : weight attributed to own capital;

$\mathrm{I}_{\mathrm{e}}$ : cost of own capital;

$\mathrm{W}_{\mathrm{u}}$ : weight attributed to third-party capital;

$\mathrm{I}_{\mathrm{u}}$ : cost of third-party capital;

T: average tax rate of the company.

\section{e) final report of Brand Value.}

This is an estimate of the "Sextantio" brand through the following parameters:

\begin{tabular}{ll}
\hline Parameter & Value \\
\hline Royalty rate & $10 \%$ \\
Average Revenues per year & $€ 2.296 .000$ \\
Annual Growth rate & $5 \%$ per year \\
Duration of residual useful life & 10 years \\
Maintenance costs $_{\text {Tax charge }}^{2}$ & $1 \%$ of turnover \\
Discounted rate & $27,9 \%$ \\
\hline
\end{tabular}

As a result of these parameters identified, the evaluation of the Sextantio Brand is therefore shown in the following table:

\begin{tabular}{llrrrrrrrr}
\hline & $\begin{array}{l}\text { Expected } \\
\text { Revenues (in } \\
\text { () }\end{array}$ & $\begin{array}{l}\text { Royalty } \\
\text { rate }\end{array}$ & $\begin{array}{r}\text { Royalty 1 } \\
\text { (in } € \text { ) }\end{array}$ & $\begin{array}{l}\text { Maintenance } \\
\text { costs (in } € \text { ) }\end{array}$ & $\begin{array}{l}\text { Royalty 2 } \\
\text { (in } € \text { ) }\end{array}$ & $\begin{array}{l}\text { Tax } \\
\text { Rate }\end{array}$ & $\begin{array}{l}\text { Net } \\
\text { Royalty }\end{array}$ & $\begin{array}{l}\text { Wacc } \\
\text { Discounted } \\
\text { Royalty }\end{array}$ \\
\hline 2019 & 2.296 .000 & $10 \%$ & 229.600 & 22.960 & 206.640 & $27,9 \%$ & 148.987 & 5,70 & 140.953 \\
2020 & 2.410 .000 & $10 \%$ & 241.000 & 24.100 & 216.900 & $27,9 \%$ & 156.385 & 5,70 & 139.973 \\
2021 & 3.133 .000 & $10 \%$ & 313.300 & 31.330 & 281.970 & $27,9 \%$ & 203.300 & 5,70 & 172.152 \\
2022 & 3.290 .000 & $10 \%$ & 329.000 & 32.900 & 296.100 & $27,9 \%$ & 213.488 & 5,70 & 171.030 \\
2023 & 3.454 .000 & $10 \%$ & 345.400 & 34.540 & 310.860 & $27,9 \%$ & 224.130 & 5,70 & 169.873 \\
2024 & 3.627 .000 & $10 \%$ & 362.700 & 36.270 & 326.430 & $27,9 \%$ & 235.356 & 5,70 & 168.762 \\
2025 & 3.808 .000 & $10 \%$ & 380.800 & 38.080 & 342.720 & $27,9 \%$ & 247.100 & 5,70 & 167.628 \\
2026 & 3.998 .000 & $10 \%$ & 399.800 & 39.980 & 359.820 & $27,9 \%$ & 259.430 & 5,70 & 166.502 \\
2027 & 4.198 .000 & $10 \%$ & 419.800 & 41.980 & 377.820 & $27,9 \%$ & 272.400 & 5,70 & 165.399 \\
2028 & 4.400 .000 & $10 \%$ & 440.000 & 44.000 & 396.000 & $27,9 \%$ & 285.500 & 5,70 & 164.005 \\
Total & & & & & & & & & \\
\hline
\end{tabular}

The economic evaluation of the Sextantio brand, as previously identified, corresponds to Euro 1,626,277 which is mindfully rounded to Euro 1,500,000.00.

\footnotetext{
${ }^{1}$ With the exception of the 2021 financial year in which revenue growth is estimated at $30 \%$.

2 The IRES and IRAP rates currently in force were taken into account for the calculation of the tax burden, as current situation in Italy.
} 


\section{Discussion}

This study is started with the process of evaluation related to the value of a brand of the Sextantio brand. The process of financial perspective of evaluation of the brand has just been carried out.

But this is not sufficient, as in this sector, throughout the last decades, various concepts of hospitality tourism have appeared against the traditional concept of tourism and hotellerie.

Starting from the RBV theory (resource based theory) which concentrates the development of a company and underlines the need to focus on resources in order to obtain the continuity of the company (Penrose, 1959; Wernerfelt, 1984; Barney, 1991), the development is moved towards the creation of competitive advantage (Porter, 1980), using resources and implementing strategies that cannot be replicated by competitors. The AD develops a unique and inimitable formula, as well as sustainably, socially, and ethically responsible. The competitive advantage that develops with the $\mathrm{AD}$ therefore becomes absolute, of a defensible type (Barney, 1991) thanks to resources:

- with value for the market;

- rare, unique or present only with reference the territorial context;

- impossibility of imitability by competitors;

- not replaceable by other resources.

The competitive advantage of an AD will be more developed by the presence and ability to feed the development, as well as by the existence of local capacities, history, knowledge handed down, wealth no longer realizable or reproducible and goods to be recovered and enhanced, from new trades. Based on these elements, an AD can become in operational terms a stock of tangible and intangible resources that characterize a territory and capable of creating a defensible competitive advantage (Lev, 2001). The challenge in this sense is therefore to work towards the implementation of management policies based on the development of exclusivity, as a threat that ADs can boast compared to traditional hotels in rural areas or urban areas.

On the basis of these premises, the results coming from the case of Sextantio.

Its on these lines, that the initial study was inspired by what was observed in Droli's study, which has identified some typical indicators in his research focalised in other territory, but in refer to $A D$, at 24 different municipalities. In Sextantio case, there are two municipalities: Santo Stefano di Sessanio in Abruzzo Region and Matera in Basilicata Region.

In this study there are different factors identified as:

1. tourist attractiveness elements of the $\mathrm{AD}$;

2. internal elements of the $\mathrm{AD}$;

3. external factors of the AD.

Following, the first elaboration referring to each of these elements, specifically with characteristic, description and KPI (key performance indicators).

Table 1. Tourist attractiveness elements of the AD Sextantio

\begin{tabular}{|c|c|c|}
\hline Characteristics & Description & KPI \\
\hline Social tranquility & $\begin{array}{l}\text { Low number of crimes against people } \\
\text { and against things }\end{array}$ & $\begin{array}{l}\text { - No. of crimes against people } \\
\text { (malicious injuries, violence, attacks } \\
\text { etc.) } \\
\text { - Muggings } \\
\text { - Thefts }\end{array}$ \\
\hline Social relationships & $\begin{array}{l}\text { Low population density, passing of } \\
\text { knowledge }\end{array}$ & - Inhabitants / km² \\
\hline $\begin{array}{l}\text { Agricultural, artisanal and } \\
\text { productive system }\end{array}$ & $\begin{array}{l}\text { Presence of agricultural enterprises, } \\
\text { artisans, "ancient" or traditional jobs }\end{array}$ & $\begin{array}{l}\text { - No. of agricultural enterprises } \\
\text { - No. of artisans } \\
\text { - No. of traditional jobs }\end{array}$ \\
\hline Animal life & $\begin{array}{l}\text { Presence of farm animals, at home, } \\
\text { protected species }\end{array}$ & $\begin{array}{l}\text { - No. of protected animal species } \\
\text { the fauna } \\
\text { - No. of accommodation facilities on } \\
\text { education and knowledge of animals } \\
\text { - Presence of national parks }\end{array}$ \\
\hline
\end{tabular}


Table 2. Internal Elements of the AD Sextantio

\begin{tabular}{|c|c|c|}
\hline Characteristics & $\begin{array}{l}\text { Description (presence } \\
\text { of) }\end{array}$ & KPI \\
\hline Available resources & $\begin{array}{l}\text { Historical, naturalistic, } \\
\text { environmental and } \\
\text { cultural resources }\end{array}$ & $\begin{array}{l}\text { - No. of historical resources (monuments, buildings, } \\
\text { churches, etc.) } \\
\text { - No. of natural resources (types of natural wealth } \\
\text { present) } \\
\text { - No. of type and variety of natural capital present in } \\
\text { the territory (quality of the air, presence of water with } \\
\text { high purifying components, presence of land } \\
\text { particularly rich in minerals, etc.) } \\
\text { - No. of cultural events }\end{array}$ \\
\hline Accessibility & $\begin{array}{l}\text { Connections to the main } \\
\text { cities }\end{array}$ & $\begin{array}{l}\text { - No. of connections with buses, trains, other types } \\
\text { of connection services } \\
\text { - No. of medical-hospital facilities to ensure the first } \\
\text { intervention in case of need }\end{array}$ \\
\hline Basic health services & $\begin{array}{l}\text { Health facilities and / or } \\
\text { referral medical services } \\
\text { for emergency response }\end{array}$ & $\begin{array}{l}\text { - No. of medical-hospital facilities to ensure the first } \\
\text { intervention in case of need }\end{array}$ \\
\hline Public institutions & Public service to citizens & - Type of public services provided by the State \\
\hline Restaurant & $\begin{array}{l}\text { Restaurants and food } \\
\text { services }\end{array}$ & $\begin{array}{l}\text { - No. of restaurants, trattorias, taverns, pizzerias, } \\
\text { wine bars, bars, pubs, ... }\end{array}$ \\
\hline Typical local products & $\begin{array}{l}\text { Products strictly referred } \\
\text { to the territory recipes }\end{array}$ & $\begin{array}{l}\text { - No. of typical products } \\
\text { - No. of DOP wines } \\
\text { - No. of recipes and culinary traditions }\end{array}$ \\
\hline
\end{tabular}

Table 3. External Elements of the AD Sextantio

\begin{tabular}{|c|c|c|}
\hline Characteristics & Description & KPI \\
\hline Human resources & $\begin{array}{l}\text { Presence of experienced } \\
\text { employee in the } \\
\text { development and } \\
\text { expansion of the CEO }\end{array}$ & $\begin{array}{l}\text { - No. of employees in the AD } \\
\text { - No. of other workers that are outside the AD, } \\
\text { but functional to the AD's activity }\end{array}$ \\
\hline Training & $\begin{array}{l}\text { Possibility to train } \\
\text { employee outside the } \\
\text { CEO }\end{array}$ & $\begin{array}{l}\text { - No. of possibilites to adopt public resources to } \\
\text { improve the reception of local people } \\
\text { - No. of schools that have seen the best advantage } \\
\text { of the tourist destination } \\
\text { for of internships operated with Italian and } \\
\text { foreign schools and universities }\end{array}$ \\
\hline $\begin{array}{l}\text { Further widespread and development } \\
\text { of AD }\end{array}$ & $\begin{array}{l}\text { Possibility to recover } \\
\text { other areas and / or to } \\
\text { expand the } \\
\text { accommodation capacity } \\
\text { of the place with other } \\
\text { neighboring villages }\end{array}$ & $\begin{array}{l}\text { - No. of rooms (variations from year to year if } \\
\text { there are) } \\
\text { - No. of agreements with the families of the } \\
\text { village to expand the AD company } \\
\text { - No. of recoveries made over the years }\end{array}$ \\
\hline Reputation & $\begin{array}{l}\text { Possibility of expressing } \\
\text { judgment towards the } \\
\text { AD }\end{array}$ & $\begin{array}{l}\text { - No. of total face-to-face comments } \\
\text { - No. of total reviews online } \\
\text { - No. of other comments (suggestions, guest tips, } \\
\text { etc.) } \\
\text { - No. of negative comments on the CEO } \\
\text { eWom support }\end{array}$ \\
\hline Networking & $\begin{array}{l}\text { Real possibility to create } \\
\text { networking with other } \\
\text { competitors or with } \\
\text { other sectors }\end{array}$ & $\begin{array}{l}\text { - No. of agreements in place with other } \\
\text { competitors } \\
\text { - No. of working agreements with others (visits to } \\
\text { educational farms, guided tours with guides, ...) } \\
\text { - No. of possible agreements with others }\end{array}$ \\
\hline
\end{tabular}

The elements of brand value showed in the above tables through a first classification studied on the Sextantio case, consists of a new way to consider the unique concept of economic value of brand related to an AD.

It is a broader definition compared to the traditional methods, however it is difficult to predict the beset way to identify a prudent method in evaluating this intangible asset, in the new formula of entrepreneurship, as AD.

\section{Conclusions}

The results of the paper are the definitions of the specific elements of the AD concept, and consequently, AD 
brand that differs from the traditional hotel brand; this study aims first to create awareness and to contribute to identifying the impact of these elements on traditional economic valuation models and how they can be incorporated. Because of the complexity of the topic, the hypothesis has been to build a model of synthesis, consisting of two parts: the first for the economic brand evaluation for Sextantio in the traditional formulas, and the second part to a first classifying of elements in the new perspective of wide brand in AD.

The originality of the work is in the definitions of the basic assumptions with which to build an economic evaluation model of the "special brand" referred to an $\mathrm{AD}$, beyond the traditional elements.

\subsection{Limitation of the Study}

The main limit of the research is that this study is still at an early stage of the building of the framework.

This study, as indeed every exploratory study, presents numerous limitations given by the uniqueness of the case study which, if on the one hand is helpful through its contribution to similar cases, on the other it presents the limits of a possible failure of generalization, despite being, at least in this first phase of research, maintained in a very generic phase and referable also to other cases of $\mathrm{AD}$, in this second part.

The limits are also contained in the quantitative part, since being the first process started in the determination of the financial value of the brand, it is understood that it must undergo successive revisions and modifications.

\subsection{Future Research}

This study is a starting point in the identification of tangible and intangible elements linked to this new hotel formula of $\mathrm{AD}$, referred to Sextantio, which will have to be further developed and "customized" with reference to this case and "aggregate" the elements of the hotel in Santo Stefano di Sessanio and those of Matera, referred to a unique brand: Sextantio.

It is for this reason that this pioneering study could give rise to new scenarios and new methods of evaluation that will be based on these new identified elements that will have to be quantified on the basis of the determinations of the KPIs that certainly must also be completed and improved.

Further research, referred to other cases of $\mathrm{AD}$, may potentially provide other elements to be included in the above classification about the elements refferred to a wide concept of $\mathrm{AD}$ brand in order to evolve this framework.

\section{References}

Aaker, D. A. (1991). Managing Brand Equity. The Free Press, New York, NY.

Alpert, M. I. (1971). Identification of determinant attributes: A comparison of models. Journal of Marketing Research, 8(2), 184-191. https://doi.org/10.1177/002224377100800205

Atkinson, A. (1988). Answering the eternal question: What does the customer want? The Cornell Hotel and Restaurant Administration Quarterly, 29(2), 12-14. https://doi.org/10.1177/001088048802900209

Avram, M., \& Zarrilli, L. (2012). The Italian model of "albergo difuso": a possible way to preserve the traditional heritage and to encourage the sustainable development of the Apuseni Nature Park. GeoJournal of Tourism and Geosites, 9(1), 32-42.

Barney, J. (1991). Firm Resources and Sustained Competitive Advantage, Journal of Management, 17(1), 99-120. https://doi.org/10.1177/014920639101700108

Blain, C., Levy, S. E., \& Brent Ritchie, J. R. (2005). Destination branding insights and practices from destination management organization. Journal of Travel Research, 43(May), 328-338. https://doi.org/10.1177/0047287505274646

Brent Ritchie, J. R., \& Brant Ritchie, J. B. (1998). The branding of tourist destination: past achievement and future challenges. Proceeding of the 1998 annual Congress of International Association of Scientific Experts in Tourism Destination Marketing; Scopes and Limitations, Marrakechi, 89-116.

Buonincontri, P., Morvillo, A., Okumus, F., \& van Niekerk, M. (2017). Managing the experience co-creation process in tourism destinations: Empirical fndings from Naples. Tourism Management, 62, 264-277. https://doi.org/10.1016/j.tourman.2017.04.014

Cadotte, E. R., \& Turgeon, N. (1988). Key factors in guest satisfaction. The Cornell Hotel and Restaurant Administration Quarterly, 28(4), 45-51. https://doi.org/10.1177/001088048802800415

Callan, R. J., \& Bowman, L. (2000). Selecting a hotel and determining salient quality attributes: A preliminary study of mature British travelers. The International Journal of Tourism Research, 2(2), 97-118. 
https://doi.org/10.1002/(SICI)1522-1970(200003/04)2:2<97::AID-JTR190>3.0.CO;2-1

Cater, E., \& Lowman, G. (1994). Ecotourism: A sustainable Option?, London: Wiley.

Chacko, H. E. (1997). Positioning a tourism destination to gain a competitive edge. Asia Pacific Journal of Tourism Research, 1(2), 69-75. https://doi.org/10.1080/10941669708721976

Chung, K. Y., Oh, S. Y., Kim, S. S., Seung, S. Y., \& Han, Y. (2004). Three representative market segmentation methodologies for hotel guest room customers. Tourism Management, 25(4), 429-441. https://doi.org/10.1016/S0261-5177(03)00115-8

Confalonieri, M. (2011). A typical Italian phenomenon: The "albergo diffuso". Tourism Management, 32, 685-687. https://doi.org/10.1016/j.tourman.2010.05.022

Cooper, C., Fletcher, J., Fyall, A., Gilbert, D., \& Wanhill, S. (2005). Tourism: Principles and practice (3th Edi). Madrid: Prentice Hall.

Cucari, N., Wankowicz, E., \& Salvatore, E. D. F. S. (2019). Rural tourism and Albergo Difuso: A case study for sustainable land-use planning, Land Use Policy, 82, 105-119. https://doi.org/10.1016/j.landusepol.2018.11.050

Dall'Ara, G. (2010). Manuale dell'Albergo Diffuso, l'idea, la gestione, il marketing dell'ospitalità diffusa. Franco Angeli, Milano.

Del Gatto, S. (2015). Recupero del patrimonio culturale dei centri minori e sviluppo del territorio attraverso l'albergo diffuso: il caso Borgo Tuf, in: XXVII Sinergie Annual Conference of Heritage. Management e Impresa: Quali Sinergie?, 471-488.

Di Clemente, E., Hernández Mogollón, J. M., \& Campón Cerro, A. M. (2014). The Albergo Diffuso: an horizontal hospitality model for rural tourism destinations of extremadura. Monográfico, 9, 159-175.

Dolnicar, S., \& Otter, T. (2003). Which hotel attributes matter? A review of previous and a framework for future research. In T. Griffin, \& R. Harris(Eds.), Proceedings of the 9th Annual Conference of the Asia Pacific Tourism Association (APTA), University of Technology Sydney, 1, 176-188.

Droli, M. (2013). Rating Rural Hamlets for their Business Start-Up Potentials: Reality or Utopia? Sabiedriba, Intergacija, Izglitiba, 6, 21-33.

Dube, L., \& Renaghan, L. M. (2000). Creating visible customer value. The Cornell Hotel and Restaurant Administration Quarterly, 4l(1), 62-72. https://doi.org/10.1177/001088040004100124

Durkin, J., \& Kolarić, M., (2016). Diffuse and Integrated Hotels As Innovative Form of Accommodation: Review of the Concept and Its Implementation in Croatia. Tourism \& Hospitality Industry, Congress Procedings, 26-38.

Eisenhard, K. M. (1989). Building Theories from case study research. Academy of Management Review, 14(4), 532-550. https://doi.org/10.5465/amr.1989.4308385

Esposito, D. F. S. (2012). Genesi ed evoluzione dell'impresa. Cedam, Padova.

Fissi S., Gori, E., \& Romolini, A. (2014). Il connubio tra impresa e territorio, il caso dell'albergo diffuso "il Borgo di Sempronio", Impresa Progetto, Electronic Journal of Management, 1, 1-14.

Giampiccoli, A., \& Saayman, M. (2014). A conceptualisation of alternative forms of tourism in relation to community development. Mediterranean Journal of Social Sciences, 5, 1667-1677. https://doi.org/10.5901/mjss.2014.v5n27p1667

Giampiccoli, A., \& Saayman, M. (2016). Community-based tourism: From a local to a global push, Acta Commercii, 16(1), a372. https://doi.org/10.4102/ac.v16i1.372

Giovannini, R., Sansone, M., Marsigalia, B., \& Colammatteo, A. (2017). Governance of private label as strategic asset: developing a brand valuation model. Journal of Governance and Regulation, 6(4), 17-29. https://doi.org/10.22495/jgr_v6_i4_p2

Gonçalves, H. M., Silva, G. M., \& Martins, T. G. (2018). Motivations for posting online reviews in the hotel industry, Psychology \& Marketing, 35, 807-817. https://doi.org/10.1002/mar.21136

Gorgo, L., \& Riggi, L. (2017). Urban traces: revitalization strategies for abandoned villages, 24th ISUF International City and territory in the Globalization Age, Conference proceedings, 843-849.

https://doi.org/10.4995/ISUF2017.2017.5938 
Guatri, L., \& Bini, M., (2011). Nuovo trattato sulla valutazione delle aziende. Milano, EGEA.

Haghkhah, A., Nosratpour, M., Ebrahimpour, A., \& Hamid, A. B. A. (2011). The impact of service quality on tourism industry. Proceedings of the 2nd International Conference on Business and Economic Research (2nd ICBER 2011), Malaysia, 13th-16th March.

Hankinson, G. (2004). The brand images of tourism destination: a study of the saliency of organic images. Journal of Product and Brand Management, 13(1), 6-14. https://doi.org/10.1108/10610420410523803

Henderson, J. C. (2007). Uniquely Singapore: A case study in destination branding. Journal of Vacation Marketing, 13(3), 261-274. https://doi.org/10.1177/1356766707077695

Ioppolo, G., Saija, G., \& Salomone, R. (2013). From coastal management to environmental management: the sustainable eco-tourism program for the mid-western coast of Sardinia (Italy). Land Use Policy, 31, 460-471. https://doi.org/10.1016/j.landusepol.2012.08.010

Jamal, T., Camargo, B. A., \& Wilson, E., (2013). Critical omissions and new directions for sustainable tourism: a situated macro-micro approach. Sustainability, 5, 4594-4613. https://doi.org/10.3390/su5114594

Jerman, M., \& Jankovic, S., (2018). The importance of Intangible Assets in the Hotel Industry: The case of Croatia and Slovenia, Scientific Annals of Economics and Business, 65(3), 333-346. https://doi.org/10.2478/saeb-2018-0017

Kastenholz, E. (2004). Management of demand as a tool in sustainable tourist destination development. Journal of Sustainable Tourism, 12, 388-408. https://doi.org/10.1080/09669580408667246

Kotler, P., \& Keller, K. L. (2006). Marketing Management, Prentice-Hall, Upper Saddle River, NJ.

Lanfranchi, M., Giannetto, C., \& De Pascale, A. (2014). The role of nature-based tourism in generating multiplying efects for socio economic development of rural areas. Calitatea, 15, 96-100.

Lev, B. (2001). Intangibles: Management, Measurement and Reporting, Washington, DC: Brookings Institution Press.

Lewis, R. C., \& Chambers, R. E. (2000). Marketing leadership in hospitality: Foundations and practices. New York: John Wiley \& Sons.

Liçaj, B. (2014). Albergo Diffuso: developing tourism through innovation and tradition: the case of Albania. Online International Interdisciplinary Research Journal, 4(3), 84-91.

Lin, C. F. (2012). Exploring the Hotel Service Personnel's Cognitive Implications toward Service Attributes and Ethics. Human Factors and Ergonomics in Manufacturing \& Service Industries, 24(1) 14-28. https://doi.org/10.1002/hfm.20349

Lockyer, T. (2005). The perceived importance of price as one hotel selection dimension. Tourism Management, 26(4), 529-537. https://doi.org/10.1016/j.tourman.2004.03.009

Moscardo, G., \& Murphy, L. (2014). There is no such thing as sustainable tourism: Re-con- ceptualizing tourism as a tool for sustainability. Sustainability, 6, 2538-2561. https://doi.org/10.3390/su6052538

Nickerson, N. P., \& Moisey, R. N. (1999). Branding a state from features to positioning. making it simple? Journal of Vacation Marketing, 5(3), 217-226. https://doi.org/10.1177/135676679900500302

Paniccia, P., \& Leoni, L. (2017). Co-evolution in tourism: the case of Albergo Difuso. Current Issues in Tourism, $0,1-28$.

Paniccia, P., Pechlaner, H., \& Valeri, M. (2007). Da borgo ad albergo. Il caso Sextantio [From villages to hotel. The case of Sextantio]. La Rivista del Turismo, 4,16-24.

Paniccia, P., Pechlaner, H., \& Valeri, M. (2010). The importance of the time of experience in the innovation of tourism business. The Sextantio Albergo Diffuso. In K. Weiermair, F. Go, P. Keller, \& H. Pechlaner (Eds.), Entrepreneurship and innovation in tourism (pp. 97-116). Berlin: Erich Schmidt Verlag.

Penrose, E.T. (1959). The Theory of the Growth of the Firm, Oxford: Oxford University Press.

Peterson, R. A. (2005). In search of authenticity. International Journal of Management Studies Research, 42, 1083-1098. https://doi.org/10.1111/j.1467-6486.2005.00533.x

Poon, W. C., \& Low, K. L. T. (2005). Are travelers satisfied with Malaysian hotels? International Journal of Contemporary Hospitality Management, 17(2/3), 217-227. https://doi.org/10.1108/09596110510591909

Porter, M. E. (1980). Competitive Strategies. New York: Free Press. 
Presenza, A., Petruzzelli, A. M., \& Sheehan, L. (2019). Innovation trough tradition in hospitality. The Italian case of Albergo Diffuso. Tourism Management, 72, 192-201. https://doi.org/10.1016/j.tourman.2018.11.020

Putnam, R. D., Leonardi, R., \& Nanetti, R. Y. (1993). Making Democracy Work: Civic Tradition in Modern Italy, Princeton University Press. https://doi.org/10.2307/j.ctt7s8r7

Simone, C., Barile, S., \& Calabrese, M. (2018). Managing territory and its complexity: a decision-making model based on the viable system approach (VsA). Land Use Policy, 72, 493-502. https://doi.org/10.1016/j.landusepol.2017.12.070

Tani, M., \& Papaluca, O. (2015). Local resources to compete in the global business: The case of Sextantio hotels. Handbook of Research on Global Hospitality and Tourism Management, 119-141. https://doi.org/10.4018/978-1-4666-8606-9.ch008

Trombino, D. (2009). L'albergo diffuso negli ordinamenti regionali: le iniziative più recenti, Disciplina del commercio e dei servizi, 8(2), 33-45.

Valeri, M., \& Paoloni, P. (2017). Competitiveness and sustainability in tourism industry: the Albergo Difuso case study. International Journal of Business Management, 12, 107-118. https://doi.org/10.5539/ijbm.v12n12p107

Vallone, C., \& Veglio, V. (2014). La valorizzazione del patrimonio artistico come driver per lo sviluppo del territorio: il caso dell'albergo diffuso. Mercati \& Competitività, 4, 109-130. https://doi.org/10.3280/MC2014-004007

Vignali, C. (2010). L'albergo diffuso: analisi giuridico economica di una forma non tradizionale di ospitalità, in Degressi, L., Franceschelli, V. (Eds.), Turismo. Diritto e diritti, Giufrè, Milano, 579-626.

Villani, T., \& Dall'Ara, G. (2015). L'Albergo Diffuso come modello di ospitalità originale e di sviluppo sostenibile dei borghi. Firenze Univeristy Press.

Wernerfelt, T. B. (1984). A resource-based view of the firm, Strategic Management Journal, 5, 171-180. https://doi.org/10.1002/smj.4250050207

Wilkins, H., Merrilees, B., \& Herington, C. (2007). Towards an understanding of total service quality in hotels. International Journal of Hospitality Management, 26(4), 840-853. https://doi.org/10.1016/j.ijhm.2006.07.006

Yin, R. (2009). Case study research: Design and methods (4th ed.). Thousand Oaks, CA: Sage Publication.

Yin, R. K. (1994). Case Study Reserach - Design and Methods. Thousand Oaks, CA: Sage Publications.

Zanda, G., Lacchini, M., \& Onesti, T. (2005). La valutazione delle aziende, Giappichelli Editore, Torino.

\section{Copyrights}

Copyright for this article is retained by the author(s), with first publication rights granted to the journal.

This is an open-access article distributed under the terms and conditions of the Creative Commons Attribution license (http://creativecommons.org/licenses/by/4.0/). 